\title{
A THEORETICAL INTERPERSONAL STYLE REPERTOIRE FOR MIDDLE-LEVEL MANAGERS
}

\author{
P KOORTZEN \\ K F MAUER \\ Department of Industrial and Organisational Psychology \\ University of South Africa
}

\begin{abstract}
The development of the interpersonal behaviour of managers has received a good deal of attention, especially in terms of the most appropriate interpersonal styles in the work context and the skills involved in developing and maintaining effective interpersonal relationships. The design of effective interpersonal development programs requires a thorough evaluation of an individual's interpersonal development needs. In order to do this, evaluators should have an understanding of the most appropriate interpersonal styles for managers. Given the aims of the investigation, the approach that was followed was to evaluate the relevant literature in this field. The theoretical goal was to study and describe the most appropriate theoretical interpersonal style repertoire of middle-level managers using the interpersonal approach, and specifically the 1982 Interpersonal Circle. The conclusions support the notion that dominant, assured, exhibitionistic, social, friendly, warm and trusting styles are the most relevant of the 16 interpersonal segments, while the assured-dominant, social-exhibitionistic and warm-friendly octants are viewed as the most appropriate.
\end{abstract}

\section{OPSOMMING}

Die ontwikkeling van die interpersoonlike gedrag van bestuurders het reeds heelwat aandag gekry. Dit geld veral vir aangeleenthede wat verband hou met die mees toepaslike interpersoonlike style binne die werkskonteks en die vaardighede wat die ontwikkeling van effektiewe interpersoonlike verhoudings onderlê. Die ontwikkeling van effektiewe interpersoonlike ontwikkelingsprogramme vereis 'n deeglike evaluering van 'n individu se interpersoonlike ontwikkelingsbehoeftes. Om dit te vermag, is dit nodig vir evalueerders om te verstaan wat die mees toepaslike interpersoonlike style vir bestuurders is. Gegee die doelwitte van die ondersoek is die metode wat gevolg is ' $n$ evaluering van die relevante literatuur in hierdie gebied. Die teoretiese doel was om die mees toepaslike teoretiese interpersoonlike stylrepertoire van middelvlak bestuurders te bestudeer en te beskryf deur gebruik te maak van die interpersoonlike benadering en spesifiek van die 1982 Interpersoonlike Sirkel. Die gevolgtrekkings steun die aanname dat dominante, versekerde, sosiale, vriendelike, warm en vertrouende style die mees relevante van die 16 interpersoonlike segmente is. In dié verband kan die versekerde-dominante, sosiale-ekshibisionistiese en warm-vriendelike oktante as die mees toepaslike beskou word.

This study found its origin in the problems associated with the evaluation and development of interpersonal behaviour of middle-level managers in industry. These problems include the following:

1. Papa (1989) claims that trainers do not always receive enough information about potential trainees which makes it difficult to design effective development programs. Hodgetts (1986) believes that ineffective development programs can lead to lower productivity, lower morale, increased absenteeism, and higher staff turnover. As a consequence, this review is an attempt to compile a theoretical model by means of which the interpersonal behaviour of middle-level managers can be evaluated.

2. Many evaluations of managers' interpersonal behaviour focus on evaluating interpersonal skills. Sopchak, Sopchak and Kohlbrenner (1993) suggest that instead of evaluating interpersonal skills, researchers should conduct personality evaluations because interpersonal skill evaluations might be too limiting and may reflect no more than interpersonal behaviour in certain contexts. This research, therefore, focuses on interpersonal styles as viewed from the interpersonal approach, rather than merely on interpersonal skills. Sullivan (1956) believes that personality manifests interpersonally and that it is no more than a hypothetical construct that can be observed in interpersonal relations. Personality, according to this author, is characterized by enduring patterns and styles that determine how people view themselves and how they react to their immediate environments. Appropriate and inappropriate interpersonal styles which are relatively more stable, were, therefore, analyzed.

Requests for copies should be addressed to: P Koortzen, koortp@unisa.ac.za
3. Though the interpersonal approach offers an applicable model, and provides techniques and instruments that can be used to evaluate interpersonal styles, a third problem exists, namely, the lack of a description of the most appropriate interpersonal styles for middle-level managers. The absence of a theoretical criterion to describe effective interpersonal styles for middle-level managers that can be used to compare the results of the individual managers therefore poses a problem. The goal of the research was consequently to study and describe the most appropriate theoretical interpersonal style repertoire for middle-level managers using the interpersonal approach - and the 1982 Interpersonal Circle in particular.

Sullivan (1956) was the first theorist to develop a complete personality theory using the interpersonal approach and he defines personality as the "... relatively enduring pattern of recurrent interpersonal situations which characterize a human life" (Sullivan, 1953, p. 111). Since his approach is not commonly used by psychologists in industry, a summary of the basic assumptions of this approach as described by Leary (1957) and Kiesler (1996) is presented below.

Whereas the focus in the study of personality from the behaviouristic and humanistic approaches - which are more commonly used in industry - is on the behaviour of the individual, the interpersonal approach focuses on interpersonal interactions or on transactions between two or more individuals. This statement derives from Leary's (1957) basic assumption which states that all interpersonal behaviours are attempts to avoid anxiety or to establish and maintain self-esteem in interpersonal interactions. To illustrate this more fully, we shall discuss some of Kiesler's assumptions in greater detail. 
The interpersonal approach focuses on human transactions rather than on individual behaviour. Behaviour is interpersonal, and it requires at least a dyad or two-person group. A central theoretical construct in this approach is the self, which is interpersonal and transactional in its development and functioning. According to this assumption, our transactions are characterized by self-presentation, which can be described as the automatic, predominantly unaware, and recurrent manner in which we centrally view ourselves. This, in turn, leads to people acting out claims on others based on the kinds of relationships they desire. These claims manifest as recurrent patterns of behaviour that can be studied over time.

These recurrent patterns of interpersonal situations represent clear combinations or blends of two basic dimensions of interpersonal behaviour, namely control (dominancesubmission) and affiliation (friendliness-hostility). The behaviour of individuals can, therefore, be studied by identifying the combinations of controlling and affiliative behaviour as it manifests in their interpersonal transactions. Interpersonal theory thus includes an interactionist position, namely, that a person's behaviours are seen as the interactive product of his or her predispositions towards transactions and situational-environmental events. This is studied by means of the person's verbal and nonverbal communication. This is clearly a complex situation, and various authors have tried to describe and present interpretations of the broad brush-strokes of interpersonal psychology. One of the most recent - and perhaps most important - authors is Donald Kiesler in his explication of what he terms the Interpersonal Circle.
Kiesler's 1982 Interpersonal Circle is the specific model that is employed in this paper. In its original, and most basic, conceptualization, the model was defined as consisting of two main axes. The horizontal axis was termed hostile versus friendly, while the perpendicular axis was defined as dominant versus submissive. The horizontal axis, it was maintained, reflected interpersonal needs for affection, while the perpendicular one reflected the need for power. Kiesler subsequently elaborated the basic model and posited a number of intermediate interpersonal behaviours which fall between the major dimensions. This model, which is presented in figure 1 , is one of the more recent empiric-conceptual reconstructions of Leary's original Circle Model.

Kiesler introduced this model as a circular taxonomy to be used to evaluate interpersonal behaviour. The circle consists of 16 interpersonal behaviour segments with two levels of behaviour in each segment representing the mild/moderate and extreme forms of the behaviour. The 16 interpersonal behaviour segments are labelled A to $\mathrm{P}$, and are positioned in the centre of the model. The mild/moderate levels of corresponding behaviours are marked A1 to P1, and the extreme levels, A2 to P2.

Apart from the model of 16 interpersonal styles, Kiesler (1996) also proposes that an octant model of behavioural segments could be used. This octant model, which is presented in figure 2, consists of eight combinations of different segments. These eight octants are evaluated by combining the scores of adjacent segments in the model.

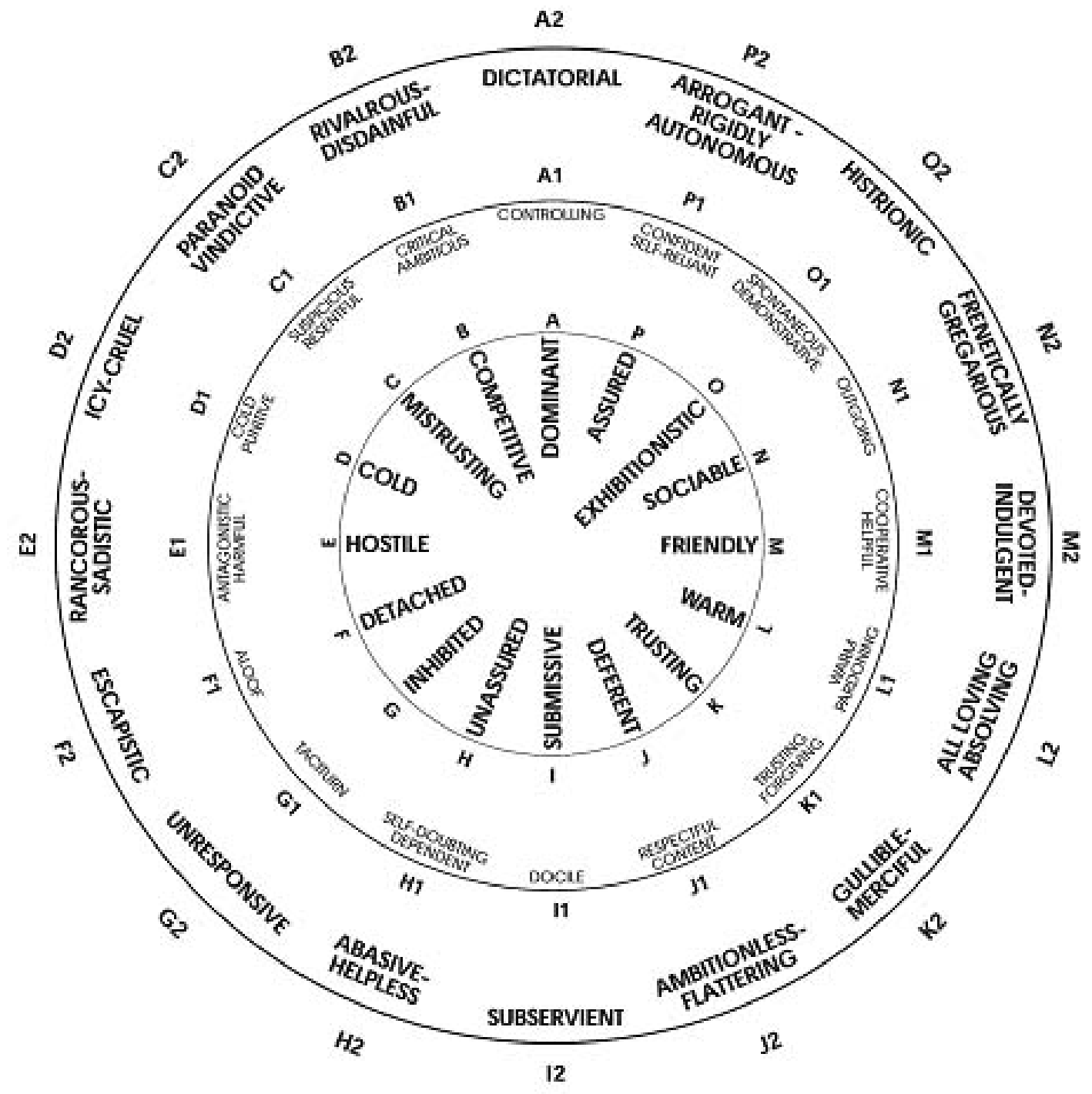

Figure 1: The 1982 Interpersonal Circle 
Using the octant approach, rather than the full range of dimensions shown in Figure 1, is often useful when empirical research is done and the sample size is not large enough to allow for so many dimensions. In addition, the distinctions between adjacent segments are often so fine that it proves to be difficult to define them in a manner which is sufficiently pure.

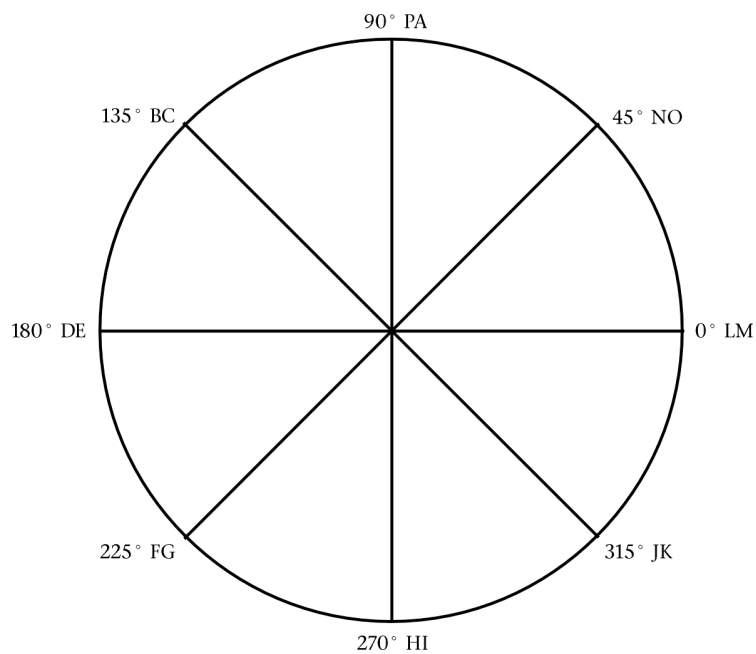

Figure 2: The octant version of the Interpersonal Circle

The octant model distinguishes eight separate interpersonal behaviours or styles which include the assured-dominant (PA), competitive-mistrusting (BC), cold-hostile (DE), detachedinhibited (FG), unassured-submissive (HI), shirking (deferent)trusting (JK), warm-friendly (LM) and social-exhibitionistic (NO) styles.

The construct of interpersonal style is defined by Kiesler (1996) as the enduring pattern of interpersonal behaviours enacted by an individual over long periods and it is presumed to demonstrate considerable temporal stability and crosssituational consistency. The construct of interpersonal style as presented by the 16 behavioural segments in the 1982 Interpersonal Circle, and the eight segments in the octant version, was used to compile a theoretical interpersonal style repertoire of appropriate styles for middle-level managers in the current study.

\section{Aim}

The theoretical aim of the research - to study and describe the most appropriate theoretical interpersonal style repertoires of middle-level managers, using the interpersonal approach and specifically the 1982 Interpersonal Circle - was attained by reviewing and analyzing relevant literature on the interpersonal behaviour of middle-level managers. The appropriateness of each interpersonal style in the Interpersonal Circle model of 16 interpersonal styles, and the simplified Octant model containing the eight major segments - was evaluated for middlelevel managers.

\section{Application}

The application of the research results is discussed with reference to the theoretical interpersonal style repertoire of middle-level managers, and the emphasis is on the conceptually more appropriate styles in the repertoire. Each interpersonal style is treated in turn, following which conclusions regarding appropriateness are reached.

\section{Competitive}

Kirkpatrick and Locke (1991) point out that effective leaders differ from other individuals in that they are achievementoriented, ambitious, energetic, and persistent, and have initiative. Stumph and Mullen (1992) state that effective middle- level managers are entrepreneurial in their attempts to provide the organization with a competitive edge. This will inevitably lead to some form of competitive behaviour.

This seems especially true in the competitive culture which Lussier and Achua (2001) define as a culture characterized by a stable business environment and an external strategic leadership focus. These authors believe that leaders of competitive cultures focus on achieving specific targets, such as improved market shares, and revenue growth or profitability. This, in turn, creates a results-oriented culture in which competitiveness, personal initiative, aggressiveness and the willingness to work hard for long hours to achieve results is valued. Middle-level managers consequently need to be aware of environmental challenges and be prepared to compete with other businesses.

Problems might, however, arise when competition also exists within the organization, such as between line managers. Kiesler (1996) explains that a person's interpersonal actions tend to initiate, invite or evoke complementary responses from the interactant, which lead to a repetition of the person's original actions. According to this theory, the complementary behaviour of competitiveness is unassuredness. This can be illustrated by the example of a competitive manager who invites his colleague to "come and look at my turnover for the month". This could cause the colleague to think that he or she is behind or not measuring up to required standards. Some competition is, however, required between middle-level managers in the competitive environment in which most organizations function.

Kiesler (1996) defines competitive (ambitious-contending) persons as people who work hard at the job at hand and who are persistent when first efforts fail. The incumbents initiate and take on new projects, and achieve and produce energetically. They seek success and admiration, and are single-minded in pursuing prestige or money. They get others to work towards their goals, they are adroit at taking credit, and they downplay or ignore others' contributions. They are eager to take on challenges and are determined to win. They impress others as being aspiring, industrious and persistent.

\section{Dominant}

Researchers agree that some form of dominant behaviour will always be part of a middle-level manager's repertoire, but that controlling and dictatorial behaviour is inappropriate. In the early seventies Kay (1974) pointed out that middle-level managers ought to accept more responsibility for making decisions. In other words, they do not constantly need to consult top management about each decision they make. Kay also stated that subordinates expect middle-level managers to be more dominant and self-assertive, especially in their negotiations with top management.

In the early nineties Albrecht (1990), Baker (1991), Lawler (1993), Jackson and Humble (1994), and Anderson and Martin (1995) emphasized the changing nature of middle-level managers' responsibilities. According to these authors, managers need to adopt training, coaching and leadership roles that require a degree of dominance and interpersonal sensitivity so as to facilitate subordinates' growth and development. The nature of dominant behaviour thus seems to be changing in the face of subordinates' needs for personal growth and creativity.

In his study of the factors that might cause the success or failure of employee involvement practices (especially the role played by middle-level managers), Fenton-O'Creevy (1998) found that positive outcomes of employee involvement were lower in organizations that experienced middle-level management resistance. Unless managers are prepared to become less dominant, employee involvement will not be facilitated. 
Buhler (2000) believes that command and control leaders, who once relied on the power inherent in their positions, have now been replaced with the managers who use personal power to build relationships. She also believes that strong interpersonal relationships are the key to getting things done by others. Mumford, Zaccaro, Harding, Jacobs and Fleishman (2000) state that effective leadership behaviour fundamentally depends on leaders' abilities to solve the kinds of complex social problems that occur in their organizations. Leaders have to be willing to tackle difficult and challenging organizational problems, and they must also be willing to exercise influence. Dominant behaviour can, therefore, be expected to influence performance, to attract individuals to situations where the necessary skills can be exercised, and to motivate subordinates in those situations. These authors believe, however, that dominance and power motives may not necessarily be desirable unless coupled with a third motive, namely social commitment.

According to Kiesler (1996), a dominant person such as, for example, a middle-level manager will display some of the following elements of dominant behaviour: An eagerness to take charge of things, an ability to lead conversations and to tell others what to do, a capacity to push hard to get his or her own way and to talk others into doing what is regarded as necessary, an ability to inform or instruct others, to persuade others to his or her viewpoint, readily to offer advice or opinions, a capability of standing up to others, resisting opposing stances and vigorously opposing others' taking charge. Such people will impress others as being decisive, forceful, and persuasive.

\section{Self-assured}

According to Nixon (1992), it is necessary for managers to be self-assured and to develop high self-esteem. He believes that it is easier for individuals to learn from previous experiences and to handle difficult situations if they feel positive about themselves. He specifically refers to the extent to which managers are criticized: he points out that it requires a high degree of self-esteem to cope with criticism and attacks, and considerable self-assuredness to react appropriately in those situations.

Confidence seems to be valued across different cultures (Neelankavil, Mathur, \& Zhang, 2000). Middle-level managers in four countries (China, India, the Philippines, and the United States of America) indicated the following dimensions of managerial performance to be the most important: planning and an ability to make decisions, self-confidence and charisma, educational achievements, communication skills, past experiences, and leadership ability. Middle-level managers clearly need to be confident in the roles they play.

One of the roles that middle-level managers often play is that of team leader. Leading a team requires specific functional and interpersonal skills. In their research on the qualities of effective team leaders Bachiochi, Elder, O'Connor, and Rogelberg (2000) found that personal characteristics such as self-confidence and emotional stability are highly regarded by the team members. They define this characteristic as having confidence in one's abilities, remaining even-tempered, patient, and dependable. Palmer (1996) believes that a sense of self-confidence is considered a key to a leader's sense of spirituality. The extent to which leaders have true selfconfidence should be reflected in their behaviour and relationships with their followers. This seems to link with some of the aspects in Kiesler's definition of assuredness.

Kiesler (1996) defines assured people as those who express their views confidently and are adroit at remaining composed and unruffled. They can be expected to rely on themselves, and they shun asking others for help. They often appear satisfied with themselves, and they find it easy to turn a conversation to their own activities or to comment on their own accomplishments. They often behave assertively in public, are eager to be noticed, and are quick to speak or act pretentiously. They find it difficult to apologize to others. They impress others as being forward, independent, and proud.

\section{Exhibitionism}

As far as exhibitionistic behaviour is concerned, Bass (1985) states that transformational leaders have to develop charismatic relationships with their subordinates, since this leads to emotional attachment. Having confidence in one's own abilities, beliefs and ideals, allows middle-level managers to facilitate the development of cooperation and self-esteem in subordinates. Managers may need to display a degree of exhibitionism if they wish to express their beliefs and ideals in a spontaneous and convincing manner.

Snavely and Farmer (2001) define charisma as a form of interpersonal attraction that inspires support and acceptance. They agree with Morehead and Griffin (1998) in that a charismatic leader's influence is based on the leader's personal charisma. They point out, however, that charisma is better thought of as existing on a continuum, rather than on an "all or nothing" basis; although charisma is definitely an asset to a leader, it can also easily lead to negative results in the absence of leader integrity. Although charismatic leaders are highly visible, approachable, and able to react quickly to issues and problems, they sometimes tend to violate the chain of command by going around direct reports, thereby undermining their direct superiors' authority.

Some characteristics of transformational and charismatic leaders seem to correspond with Kiesler's (1996) description of exhibitionistic people: that is, people who find it easy to express their views and to take clear stands on issues. They often seem to talk continuously. They are adroit at embellishing stories and can be expected to exaggerate and dramatise. Their statements frequently just pop out and their conversation are often emotionally charged. They readily make startling comments and are comfortable about making loaded statements. They tend to make hasty decisions and are quick to jump to action. They impress others as being dramatic, perky, and uninhibited.

Social

One of the components of this interpersonal style as described by Kiesler (1996) concerns individuals who attempt to become involved with others, and to involve them in activities. Hautaluoma, Dickinson and Inanda (1992), who researched the personality types of middle-level managers, found that the high leadership type was the most successful. This type of manager is characterized by attempts to involve others and they focus on the planning and coordination of the contributions made by others in the work context. Such managers are also social individuals who find it easy to make friends, and are known to be good conversationalists.

In the course of their research into the priorities that development areas should receive in management development programs Blakely, Martinec and Lane (1994) found that human relations are equally important for top, middle and lower management. Rashid and Dar (1994) support this by stating that managers can satisfy their subordinates' basic needs for acknowledgement and appreciation by listening and communicating effectively.

Bachiochi et al. (2000) found that team members value interpersonal skills such as conflict management skills, persuasion and influence, coaching/mentoring and understanding/support. The latter two skills, in particular, seem to link with Kiesler's definition of the social style that focuses on sharing and being approachable. These styles are required in the coaching and mentoring roles that middle-level managers often play. 
The following more thorough description of social people is provided by Kiesler (1996): social people are those who are quick to notice and acknowledge others, who eagerly initiate contact with them and who seek to make others feel welcome. They are comfortable at initiating conversations, and chat easily with others. They are eager to seek others' company and to invite others to participate in activities. They enjoy being with others and attempt to mix widely. They are adroit at inquiring into others' activities and are ready to relate their own experiences. They impress others as being approachable, interested, and neighbourly.

\section{Friendly}

Frohman and Jackson (1993) point out that the changing roles of middle-level managers have led to a change in their power base. These authors believe that in the past middle-level managers used their power to control. What is now required is for managers to manage in a friendlier more and empowering way. This empowering style involves encouraging subordinates, building on their ideas, giving recognition, and praising enthusiasm.

Pettit, Vaught and Trewatha (1993) agree with this view and believe that effective interpersonal and communication skills are not only necessary for delegating tasks, but also for the development of subordinates. They maintain that the changing roles of middle-level managers require that they become more involved in the development of subordinates' knowledge and skills. This clearly requires a supportive interpersonal style.

In more recent research, Conway (1999) found that managers' evaluations of the importance of different performance categories corresponded with that of their supervisors and peers. All three groups in the investigation indicated that interpersonal facilitation is the second most important performance category after job dedication. The author describes the interpersonal facilitation dimension as effectiveness in interpersonal relations, building and mending relationships, compassion and sensitivity, putting people at ease, cooperation and consideration. Conway (2000) also found that the managerial development construct of interpersonal effectiveness correlated with empathy and agreeableness. These seem to be some of the traits that subordinates and peers expect from managers.

Sosik and Godshalk (2000) investigated the links between different mentor leadership behaviours and the protégés' perceptions of the mentoring they received. Their findings revealed that the more mentoring protégés received, the lower was their job-related stress. They believe this to be the result of emotional and self-concept development support.

The supportive and consideration aspects are emphasized by Kiesler (1996) in his elucidation of a friendly person. He defines such persons as those who try hard to be thoughtful of others and who are careful to respect others' rights. They readily cooperate and are ready to play their part. They can be expected to speak softly and tactfully, they find it easy to remain patient and comfort others, they seem eager to accede to others' requests, and they are quick to offer help. They impress others as being courteous, pleasant, and supportive.

\section{Warm}

In the course of their research into the psychological distance in relationships between managers and subordinates Salzmann and Grasha (1991) found that managers judge the interpersonal distance to be smaller than do their subordinates. This implies that managers might think they have strong affective links with subordinates, while subordinates, on the contrary, might feel emotionally isolated. Their research also emphasized the importance of emotional support in a variety of managersubordinate interactions such as flexibility to change the content of workers' jobs, protection of workers, willingness to help workers with work-related problems, and being available for workers to discuss their problems. This implies creating a positive emotional climate.

In a related study Sinclair and Hintz (1991) found that managers evaluate each other by the way they delegate, communicate and listen, as well as on the extent to which they exhibit a caring, supportive and dedicated attitude. The importance of warm relationships is thus emphasized by both subordinates and managers. Some authors also consider compassion - a phenomenon which clearly cannot exist in the absence of warmth - to be an important trait for leaders (Couto, 2000).

Berr, Church and Waclawski (2000) used the MyersBriggs Type Indicator to investigate the links between personality preferences and managerial behaviours. They found that managers who had a preference for considering others' feelings and emotions as a means for making decisions tended to rate themselves, and were rated by their direct reports, as being more skilled at relationship and change management behaviours. Their research also suggests that managers with stronger feeling preferences are indeed more attuned to interpersonal relationships and the process of providing feedback and recognition to direct reports. Some of these aspects correspond with Kiesler's definition of warmth.

Kiesler (1996) describes people of this kind as those who find it hard to judge others, who demand little of them, and who treat others leniently. They prefer to impose easy discipline, they excuse transgressions readily, and they find it difficult to correct others. They are quick to accept others, and find it easy to express warmth and approval. They are eager to understand others' problems, to support their good efforts, and are adroit at finding others' good qualities. They impress others as being affectionate, soft-hearted, and sympathetic.

\section{Trust}

Nixon (1992) emphasised the importance of social skills that are required to build reciprocal supportive relationships on the basis of honesty and trust. This, however, does not imply a naive trust to the point where it could be abused. According to Early (1986), trust increases the acceptance of information while the exchange of information at higher levels in the organization is facilitated by it (Robbins, 1998). Middle-level managers play an important role in this relationship of trust as a result of the position which they occupy between upper and lower management.

Lussier and Achua (2001) describe the Leader-Member Exchange (LMX) theory in an attempt to understand the quality of each dyadic relationship and its effect on organizational outcomes over time. Brower, Schoorman and Tan (2000) propose a model of relational leadership based on a review of leader-member exchange and interpersonal trust. In this model, it is asserted that the LMX relationship is built through interpersonal exchanges in which parties to the relationship evaluate the ability, benevolence and integrity of each other. These perceptions, in turn, influence the behaviours of the parties in the relationship. Middle-level managers, therefore, need to be aware of the perceptions that subordinates have about them, and the influence this has on the trust in the relationship. They also need to be aware of their perceptions of others, how they present themselves in different relationships, and the extent to which this facilitates or inhibits the development of trust in the relationship. This seems to be in line with a number of aspects in Kiesler's definition. 
Kiesler (1996) describes trusting people as those who find it easy to trust others, are unguarded around them, and who tend to be taken advantage of by others. They are quick to rely on others' claims and prefer to believe in others' good intentions. They are slow to accuse others of harmful intent, they easily overlook insults and injuries, and are quick to accept apologies. They readily confide in others and candidly reveal their own intentions and plans. They are comfortable in admitting that others are justified when they blame them. They impress others as being candid, naive, and unsuspecting.

\section{CONCLUSION}

The literature confirms the appropriateness of some of the interpersonal styles for middle-level managers. The theoretical analysis of the interpersonal style repertoire of these managers, based on the Interpersonal Circle consisting of 16 styles, has confirmed that the competitive, dominant, assured, exhibitionistic, social, warm, friendly, and trusting interpersonal styles are not only applicable, but are even looked for in the execution of the different tasks of middlelevel managers.

Very little evidence was found in the literature to support the appropriateness of any of the other interpersonal styles. A major deduction that can be made on the grounds of this theoretical interpersonal style repertoire is that the assured-dominant (PA), warm-friendly (LM), and social-exhibitionistic (NO) octant styles ought to be included in an octant profile of middle managers. The mistrusting and shirking components of the mistrusting-competitive and shirking-trusting octants should, however, be excluded. These profiles can be used as criteria in the development of appropriate assessment instrumentation, when evaluating the interpersonal styles of managers empirically, in the development of effective interpersonal skills among a variety of groups, and also in honing managerial skills and competencies.

A major advantage of this approach is that it provides more detail in terms of the analysis of interpersonal styles, as opposed to many other instruments which provide a single dimension which is supposed to describe all interpersonal behaviour. The investigation presented in this paper was focused largely on an analysis of theoretical aspects and identifying appropriate interpersonal style for middle managers. It is self-evident that this phase ought to be followed up by a thorough empirical investigation of the applicability of the theory.

\section{REFERENCE}

Albrecht, K. (1990). Service within: Solving the middle management leadership crisis. Homewood, Ill: Irwin.

Anderson, C. M. \& Martin, M. M. (1995). Why employees speak to co-workers and bosses: Motives, gender and organisational satisfaction. Journal of Business Communication, 23 (3), 249265.

Bachiochi, P. D., Elder, A. E., O'Connor, M. S. \& Rogelberg, S. G. (2000). The qualities of an effective team leader. Organization Development Journal, 18 (1), 11-27.

Baker, M. A. (1991). Gender and verbal communication in professional settings: A review of research. Management Communication Quarterly, 5, 36-63.

Bass, B. M. (1985). Leadership and performance beyond expectations. New York: Free Press.

Berr, S. A., Church, A. H. \& Waclawski, J. (2000). The right relationship is everything: Linking personality preferences to managerial behaviors. Human Resource Development Quarterly, 11 (2), 133-157.

Blakely, G. L., Martinec, C. L. \& Lane, M. S. (1994). Management development programs: The effects of management level and corporate strategy. Human Resources Development Quarterly, 5 (1), 5-19.

Brower, H. H., Schoorman, F. D. \& Tan, H. H. (2000). A model of relational leadership: The integration of trust and leader-member exchange. Leadership Quarterly, 11 (2), 227-250

Buhler, P. M. (2000). Managing in the new millennium. Supervision, 61 (6), 16-19.

Conway, J. M. (1999). Distinguishing contextual performance from task performance for managerial jobs. Journal of Applied Psychology, 84 (1), 3-13.

Conway, J. M. (2000). Managerial performance development constructs and personality correlates. Human Performance, 13 (1), 23-46.

Couto, R. A. (2000). Community health as social justice: Lessons on leadership. Family Community Health, 23 (1), 1-17.

Early, P.C. (1986). Trust, perceived importance of praise and criticism, and work performance: An evaluation of feedback in the United States and England. Journal of Management, 12, 457-473.

Frohman, A. L. \& Jackson, L. W., (1993). The middle management challenge. New York: McGraw-Hill.

Fenton-O'Creevy, M. (1998). Employee involvement and the middle manager: Evidence from a survey of organizations. Journal of Organizational Behavior, 19, 67-85.

Hautaluoma, J. E., Dickinson. T. L. \& Inanda, A. R. (1992). Traits patterns, background characteristics, managerial styles, and job practices of industrial middle managers. Journal of Social Psychology, 132 (2), 201-215.

Hodgetts, R. M. (1986). Management: Theory, process and practice. New York: Academic.

Jackson, D. \& Humble, J. (1994). Middle managers: New purpose, new directions. Journal of Management Development, 13 (3), 15-21.

Kay, E. (1974). The crisis in middle management. New York: Amacon.

Kiesler, D. J., Goldston, C. S. \& Schmidt, J. A. (1991). Manual for the Check List of Interpersonal Transactions-Revised (CLOIT-R) and the Check List of Psychotherapy TransactionsRevised (CLOPT-R). Richmond: Virginia Commonwealth University.

Kiesler, D. J. (1996). Contemporary interpersonal theory and research: Personality, psychopathology, and psychotherapy. New York: Wiley.

Kirkpatrick, S. A. \& Locke, E. A. (1991). Leadership: Do traits matter? Academy of Management Executive, 5 (2), 48-60.

Lawler, J. (1993). Managerial stereotypes in use. Leadership and Organizational Development, 14 (1), iv-v.

Leary, T. (1957). Interpersonal diagnosis of personality. New York: Donald.

Lussier, R. M. \& Achua, C. F. (2001). Leadership: Theory, application, skill development. Cincinnati: South-Western College Publishing.

Morehead, G. \& Griffin, R. W. (1998). Organizational behavior: Managing people and organizations. Boston: Houghton Mifflin.

Mumford, M. D., Zaccaro, S. J., Harding, F. D., Jacobs, T. O. \& Fleishman, E. A. (2000). Leadership skills for a changing world: solving complex social problems. Leadership Quarterly, 11 (1), 11-35.

Neelankavil, J. P., Mathur, A. \& Zhang, M. Y. (2000) Determinants of managerial performance: A cross-cultural comparison of the perceptions of middle-level managers in four countries. Journal of International Business Studies, 31 (1), 121-140.

Nixon, B. (1992). Developing a new culture for organisations in the 90's. Management Education and Development, 23 (1), 3345.

Papa, M. J. (1989). A comparison of two methods of managerial selection. Management Communication Quarterly, 3, 191-218.

Palmer, P. J. (1996). Leading from within. Noetic Science Review, Winter, 32-47. 
Pettit, J. D., Vaught, B. C. \& Trewatha, R. L. (1993). Interpersonal skill training: A prerequisite for success. Business, Apr-Jun.

Rashid, M. \& Dar, J. (1994). Current managerial styles and effective managers. Management Services, 38 (8), 16-17.

Robbins, S. P. (1998). Organizational behavior. Upper Saddle River: Prentice-Hall.

Salzmann, J. \& Grasha, A. F. (1991). Psychological size and psychological distance in manager-subordinate relationships. Journal of Social Psychology, 13 (5), 629-646.

Sinclair, A. \& Hintz, P. (1991). Developing managers: Reexamining ten myths about MBAs and managers. Journal of Management Development, 10 (7), 53-65.

Snavely, W. B. \& Farmer, R. T. (2001). Organizational leadership: An alternative view and implications for managerial education.
Paper presented at the Management Education Division of the Midwest Academy of Management, Toledo.

Sopchak, A. L., Sopchak, A. M. \& Kohlbrenner, R. J. (1993). Interpersonal relatedness from projective drawings. Springfield: Charles Thomas.

Sosik, J. J. \& Godshalk, V. M. (2000). Leadership styles, mentoring functions received, and job-related stress: A conceptual model and preliminary study. Journal of Organizational Behavior, 21, 365-390.

Stumph, S. A. \& Mullen, T. P. (1992). Taking charge: Strategic leadership in the middle game. Englewood Cliffs, NJ.: Prentice -Hall.

Sullivan, H. S. (1956). Clinical studies in psychiatry. New York: Norton. 